\title{
CYP2C8*7 Allele
}

National Cancer Institute

\section{Source}

National Cancer Institute. CYP2C8*7 Allele. NCI Thesaurus. Code C46035.

Human CYP2C8*7 allele is located in the vicinity of $10 \mathrm{q} 23.33$ and is approximately $33 \mathrm{~kb}$ in length. This allele, a variant form of the CYP2C8 wild-type allele, encodes cytochrome P450 2C8*7 protein. The CYP2C8*7 allele exhibits a clinically-relevant SNP (c.556C>T) in exon 4 that results in a R186X coding change. This alteration yields a truncated cytochrome $\mathrm{P} 4502 \mathrm{C} 8 * 7$ protein that is enzymatically inactive. 